\title{
Ultra-high speed fiber-optic data transmission with a single chip source
}

David Moss ${ }^{1}$

${ }^{1}$ Affiliation not available

June 21, 2021

\section{Hosted file}

Moss data transmission Res Sq posted.pdf available at https://authorea.com/users/418067/ articles/526961-ultra-high-speed-fiber-optic-data-transmission-with-a-single-chip-source 